\title{
Prolactin induction of insulin gene expression: the roles of glucose and glucose transporter-2
}

\author{
A Petryk ${ }^{1}$, D Fleenor ${ }^{1}$, P Driscoll ${ }^{1}$ and M Freemark $^{1,2}$ \\ ${ }^{1}$ Department of Pediatrics, Duke University Medical Center, Durham, North Carolina 27710, USA \\ ${ }^{2}$ Department of Cell Biology, Duke University Medical Center, Durham, North Carolina 27710, USA \\ (Requests for offprints should be addressed to M Freemark, Duke University Medical Center, Pediatric Endocrinology, 314 Bell Building, Box 3080, Durham, \\ North Carolina, 27710, USA; Email: FREEM001@mc.duke.edu)
}

\begin{abstract}
Previous studies have shown that lactogenic hormones stimulate beta-cell proliferation and insulin production in pancreatic islets. However, all such studies have been conducted in cells incubated in medium containing glucose. Since glucose independently stimulates beta-cell replication and insulin production, it is unclear whether the effects of prolactin (PRL) on insulin gene expression are exerted directly or through the uptake and/or metabolism of glucose.

We examined the interactions between glucose and PRL in the regulation of insulin gene transcription and the expression of glucose transporter-2 (glut-2) and glucokinase mRNAs in rat insulinoma (INS-1) cells. In the presence of $5 \cdot 5 \mathrm{mM}$ glucose, the levels of preproinsulin and glut-2 mRNAs in PRL-treated cells exceeded the levels in control cells $(1 \cdot 7$-fold, $P<0 \cdot 05$ and 2 -fold, $P<0 \cdot 05$ respectively). The maximal effects of PRL were noted at 24-48 h of incubation. PRL had no effect on the levels of glucokinase mRNA. The higher levels of glut-2 mRNA were accompanied by an increase in the number of cellular glucose transporters, as demonstrated by a $1 \cdot 4-$ to $2 \cdot 4$-fold increase in the uptake of 2-deoxy-D- $\left[{ }^{3} \mathrm{H}\right]$ glucose in PRLtreated INS-1 cells $(P<0 \cdot 001)$.
\end{abstract}

These findings suggested that the insulinotropic effect of PRL is mediated, in part, by induction of glucose transport and/or glucose metabolism. Nevertheless, even in the absence of glucose, PRL stimulated increases in the levels of preproinsulin mRNA (3.4-fold higher than controls, $P<0 \cdot 0001)$ and glut-2 mRNA (2-fold higher than controls, $P<0 \cdot 01)$. These observations suggested that PRL exerts glucose-independent as well as glucose-dependent effects on insulin gene expression. Support for this hypothesis was provided by studies of insulin gene transcription using INS-1 cells transfected with a plasmid containing the rat insulin 1 promoter linked to a luciferase reporter gene. Glucose and PRL, alone and in combination, stimulated increases in cellular luciferase activity. The relative potencies of glucose $(5.5 \mathrm{mM})$ alone, PRL alone, and glucose plus PRL in combination were $2 \cdot 2(P<0 \cdot 001), 3 \cdot 4$ $(P<0 \cdot 01)$, and $7.9(P<0 \cdot 0001)$ respectively. Our findings suggest that glucose and PRL act synergistically to induce insulin gene transcription.

Journal of Endocrinology (2000) 164, 277-286

\section{Introduction}

The second half of pregnancy is a diabetogenic state characterized by insulin resistance, glucose intolerance, and fasting and postprandial hyperinsulinemia. Studies in experimental animals indicate that the hyperinsulinemia of pregnancy derives from expansion of the mass of pancreatic beta cells, induction of insulin synthesis, and an increase in glucose-stimulated insulin secretion (Hellman 1960, Green \& Taylor 1972, Bone \& Taylor 1976, Parsons et al. 1995). Although the factors responsible for these adaptive changes in islet function during pregnancy remain poorly defined, a role for the lactogenic hormones prolactin (PRL) and placental lactogen is suggested by three lines of evidence: first, the increase in maternal insulin production during mid- to late pregnancy coincides with increases in maternal plasma levels of placental lactogen and, in humans, PRL (Ogren \& Talamantes 1988, Parsons et al. 1992); secondly, the number of islet cell binding sites for PRL and placental lactogen and the pancreatic levels of PRL receptor mRNA increase during pregnancy (Moldrup et al. 1993, Sorenson \& Stout 1995); and thirdly, placental lactogen and PRL stimulate beta-cell proliferation, insulin production, and glucose-dependent insulin secretion in pancreatic islet cells in culture (Sorenson et al. 1987a, 1993, Brelje \& Sorenson 1991, Hellerstrom et al. 1991, Brelje et al. 1993, 1994).

The cellular mechanisms by which lactogens stimulate insulin production in pancreatic beta cells are poorly 
understood. All previous investigations of lactogen action in pancreatic islets have been conducted using culture medium that contains glucose. Since glucose independently stimulates beta-cell replication and insulin production (Docherty \& Clark 1994, Philippe et al. 1994) it is unclear whether the effects of lactogens are exerted directly or through the uptake and/or metabolism of glucose. A role for glucose transport and/or glucose metabolism in lactogen action is suggested by studies in which prolonged exposure of islets to PRL increased cellular levels of immunoreactive glucose transporter 2 (glut-2) and glucokinase, as assessed by Western blot (Weinhaus et al. 1996).

To clarify the roles of glucose transport and glucose metabolism in lactogen action, we examined the interactions between glucose and PRL in the regulation of insulin gene transcription and the expression of glut- 2 and glucokinase mRNAs in rat insulinoma (INS-1) cells. We also examined the effects of PRL on INS-1 cell uptake of 2 -deoxyglucose. We selected INS-1 cells as an in vitro model of pancreatic beta cells because these cells are highly differentiated and resemble pancreatic beta cells both morphologically and functionally (Asfari et al. 1992). INS-1 cells have been used previously by many investigators to study the regulation of insulin gene expression, glut-2 gene expression, and insulin secretion in response to glucose and other physiological secretagogues (Philippe et al. 1994, Waeber et al. 1994, Asfari et al. 1995, Frödin et al. 1995, Sekine et al. 1996). Moreover, INS-1 cells express PRL receptor mRNA and lactogenic binding activity (Asfari et al. 1995), making them suitable for the study of PRL action.

\section{Materials and Methods}

\section{Cell culture}

INS-1 cells (kindly provided by M Asfari, INSERM, Paris, France) were incubated at $37^{\circ} \mathrm{C}$ in RPMI 1640 medium (11.1 mM glucose; Life Technologies, Grand Island, NY, USA) supplemented with $10 \%$ fetal calf serum (FCS), $50 \mu \mathrm{M}$ 2-mercaptoethanol, $1 \mathrm{mM}$ pyruvic acid, $10 \mathrm{mM}$ HEPES, and 1\% antibiotic-antimycotic solution. When the cells were nearly confluent, the medium was changed to 'basal medium' (Dulbecco's modified essential medium (DMEM) $5.5 \mathrm{mM}$ glucose supplemented with $0 \cdot 1 \%$ human serum albumin, $10 \mu \mathrm{g} / \mathrm{ml}$ human transferrin, $0 \cdot 1 \mathrm{nM}$ tri-iodothyronine $\left(\mathrm{T}_{3}\right), 50 \mu \mathrm{M}$ ethanolamine, $50 \mu \mathrm{M}$ phosphoethanolamine, and $1 \%$ antibioticantimycotic solution; all from Sigma Chemical Co., St Louis, MO, USA) containing either PRL (ovine (o) PRL, $1 \mu \mathrm{g} / \mathrm{ml}$; NIDDK-NIH, Bethesda, MD, USA) or diluent. The medium was changed daily.

To explore directly the role of glucose in PRL action, we employed two approaches: first, the cells were preincubated with cytochalasin $\mathrm{B}(5-50 \mu \mathrm{M})$, which inhibits cellular glucose uptake. The cells were then incubated with PRL or diluent in the presence of cytochalasin B for periods ranging from 1 to $24 \mathrm{~h}$. These experiments were impossible to interpret because the cytochalasin B, even at very low concentrations, proved to be highly toxic to the cells. In the second approach, the INS-1 cells were preincubated in 'basal medium' overnight; the medium was then replaced with serum-free, glucose-free DMEM (supplemented with $0 \cdot 1 \%$ human serum albumin, $10 \mu \mathrm{g} / \mathrm{ml}$ human transferrin, $0 \cdot 1 \mathrm{nM} \mathrm{T}_{3}, 50 \mu \mathrm{M}$ ethanolamine, $50 \mu \mathrm{M}$ phosphoethanolamine, $1 \%$ antibioticantimycotic solution, and $1 \mathrm{mM}$ sodium pyruvate as a source of carbohydrate). The cells were incubated in this glucose-free DMEM for $2 \mathrm{~h}$ prior to, and for up to $24 \mathrm{~h}$ after, the addition of oPRL or diluent. Under these conditions, the concentration of glucose in the culture medium was below the limits of detectibility. All cell culture materials were obtained from Life Technologies, Frederick, MD, USA unless specified otherwise.

\section{$R N A$ extraction and Northern blot analysis}

Total RNA was extracted from INS-1 cells using TRI REAGENT (Molecular Research Center, Inc., Cincinnati, OH, USA). For the experiments in glucosecontaining medium, total RNA was isolated at various time-points between 3 and $72 \mathrm{~h}$ of incubation. For the experiments in glucose-free medium, total RNA was isolated at various time-points between 4 and $24 \mathrm{~h}$ of incubation. Gene expression was assessed by Northern blot analysis. Twenty micrograms of total RNA were electrophoresed on 1\% agarose gels and blotted on nylon membranes. The cDNA probe for rat preproinsulin-I (kindly provided by R Liddle, Duke University, USA) was a $700 \mathrm{bp}$ EcoRI-BamHI fragment containing the entire coding sequence for the peptide. The probe for rat glut-2 (kindly provided by G Bell, University of Chicago, IL, USA) was a $1.5 \mathrm{~kb}$ EcoRI insert encoding bases 105 through 1648 of the glut-2 cDNA. The probe encoding rat islet glucokinase (kindly provided by $\mathrm{M}$ Magnuson, Vanderbilt University, USA) was a KpnI-XbaI fragment of $1450 \mathrm{bp}$ containing the entire coding sequence for the peptide. The probe for rat insulin-like growth factor-II (IGF-II; kindly provided by A J D'Ercole, University of North Carolina, NC, USA), complementary to $241 \mathrm{bp}$ of the E-domain and $34 \mathrm{bp}$ of the $3^{\prime}$-untranslated region, was derived from a $275 \mathrm{bp}$ RsaI fragment of a rat IGF-II cDNA. The cDNA probes were labeled with digoxigenin using the Boehringer Mannheim High Prime kit (Boehringer Mannheim Co., Indianapolis, IN, USA). The probes were precipitated with ethanol, dried, and solubilized. The probes were added to the hybridization mixture, which contained $5 \times \mathrm{SSC}, 0 \cdot 1 \% \mathrm{~N}$-lauroylsarcosine, $0.02 \%$ SDS, and 1\% blocking reagent (Boehringer Mannheim Co.). The hybridizations were performed at $60{ }^{\circ} \mathrm{C}$ overnight. The membranes were washed twice at 
$60{ }^{\circ} \mathrm{C}$ in $2 \times \mathrm{SSC}$ with $0 \cdot 1 \%$ SDS (15 min each), twice with $0.5 \times$ SSC with $0.1 \%$ SDS (15 min each), and once with $0 \cdot 1 \times$ SSC with $0 \cdot 1 \%$ SDS $(10 \mathrm{~min})$, and then rinsed with malate buffer. The membranes were blocked in blocking solution (Boehringer Mannheim Co.) for $1 \mathrm{~h}$ and then in the presence of anti-digoxigenin-alkaline phosphatase (1:5000) for $30 \mathrm{~min}$. The membranes were washed in malate buffer for $15 \mathrm{~min}$ three times. Chemiluminescent detection of digoxigenin-labeled probes was performed by applying CSPD $(10 \mu \mathrm{g} / \mathrm{ml}$; Tropix, Bedford, MA, USA) diluted in buffer $3(100 \mathrm{mM}$ Tris$\mathrm{HCl}, \mathrm{pH}$ 9·5, $100 \mathrm{mM} \mathrm{NaCl}, 1 \mathrm{mM} \mathrm{MgCl} 2)$ and exposing the membranes to Hyperfilm ECL (Amersham Life Science, Elk Grove, IL, USA) for 5-30 min. The films and the corresponding ethidium bromide $(\mathrm{EtBr})$-stained gels were scanned using an ARCUS II scanner (AGFA). The images were processed for densitometric analysis using the NIH image program from Scion Corporation. The levels of mRNA estimated by densitometric analysis of Northern blots were normalized for the amounts of total RNA loaded on the gels by calculating the ratio of specific mRNA to the corresponding total RNA as assessed by $\mathrm{EtBr}$ staining. Similar or identical results were obtained when the levels of insulin, glut-2, glucokinase, or IGF-II mRNAs were normalized to levels of cyclophilin mRNA, assessed by hybridizations using a digoxigenin-labeled cDNA encoding bases 66-629 of rat cyclophilin (Freemark et al. 1995).

\section{Luciferase reporter plasmid construct}

A portion of the rat insulin-I promoter (kindly provided by G Bell) beginning at -383 bases and extending through the first untranslated exon, the first intron, and the first $11 \mathrm{bp}$ of the second exon $(-383$ to +172$)$ was generated by PCR and cloned into the luciferase reporter plasmid pGL3 (Promega, Madison, WI, USA). The resulting plasmid was sequenced to confirm its identity with the known insulin promoter.

\section{Transient luciferase assays}

Circular reporter plasmid was electroporated into INS-1 cells using a Bio-Rad Gene Pulser (Bio-Rad Laboratories, Richmond, CA, USA) set at $270 \mathrm{mV}, 960 \mu \mathrm{F}$, and infinite resistance. The transfected cells were allowed to recover for $24 \mathrm{~h}$ in RPMI containing 10\% FCS. The medium was then changed to 'basal medium' $(0-30 \mathrm{mM}$ glucose) with or without oPRL. After an additional 24-h incubation the cells were trypsinized, washed with phosphate-buffered saline (PBS), resuspended in luciferase buffer $(100 \mathrm{mM}$ sodium phosphate $\mathrm{pH} 7 \cdot 8,3 \mathrm{mM} \mathrm{MgCl}_{2}, 1 \mathrm{mM}$ dithiothreitol), and lysed upon the addition of 1\% NP-40 (Sigma). The lysate was clarified by centrifugation. Luciferase activity was determined by incubating the cell extract with luciferin in a buffer containing $50 \mathrm{mM}$ glycylglycine, $20 \mathrm{mM} \mathrm{MgSO} 4,7 \mathrm{mM} \mathrm{ATP}$, and $0.7 \mathrm{mg} /$ $\mathrm{ml}$ bovine serum albumin (BSA). The light produced was measured using a luminometer. Aliquots of cell extracts were analyzed for protein content using the Bio-Rad protein assay (Bio-Rad Laboratories). Transfection efficiency was assessed by measurement of beta-galactosidase activity in cell lysates (Sambrook et al. 1989) following cotransfection of INS-1 cells with an RSV-betagalactosidase (RSV-beta-GAL) plasmid (kindly provided by S Langdon, Duke University, USA). Unless specifically noted, all chemicals used in the luciferase assay were obtained from Sigma Chemical Co.

\section{Glucose transport assay}

INS-1 cells were washed with PBS and preincubated in 'basal medium' with or without oPRL $(1 \mu \mathrm{g} / \mathrm{ml})$ for $48 \mathrm{~h}$. The cells were then washed twice and incubated for $30 \mathrm{~min}$ at $37^{\circ} \mathrm{C}$ in glucose-free PBS containing $1 \%$ BSA. After two additional washes with PBS, the cells were incubated with 2 -deoxy-D- $\left[{ }^{3} \mathrm{H}\right]$ glucose $(1 \mu \mathrm{Ci} / \mathrm{ml}$; Amersham Life Science) for 1, 2, 4, or 16 min. 2-deoxy$\mathrm{D}-\left[{ }^{3} \mathrm{H}\right]$ glucose uptake was also measured in the presence of unlabeled 2-deoxyglucose (Sigma Chemical Co.), which was added in 10000 -fold excess in order to block specific uptake of the labeled 2-deoxyglucose. The uptake was terminated by washing the cells rapidly with ice-cold PBS containing 0.2 $\mathrm{mM}$ phloretin (Sigma Chemical Co.). Cells were solubilized in $0 \cdot 1 \%$ SDS, and aliquots were taken for counting (Tai et al. 1990). The amount of protein in each sample was assessed by using the Bio-Rad protein assay (Bio-Rad Laboratories). Counts obtained in the presence of excess 2-deoxyglucose were subtracted from those obtained in its absence to quantify specific uptake of the radiolabeled glucose.

\section{Statistics}

Data are presented as the means \pm s.E. Each experiment was repeated at least three times with duplicate or triplicate values within each group. Statistical differences between sample means were assessed by ANOVA, followed by a post-hoc Tukey's multiple comparison test. The level of significance was determined as $P<0 \cdot 05$. The levels of mRNA estimated by densitometric analysis of Northern blots were normalized for the amounts of total RNA loaded on the gels by calculating the ratio of specific mRNA to the corresponding total RNA as assessed by EtBr staining. The ratios were then used for statistical analysis.

\section{Results}

Our initial experiments were designed to examine the effects of PRL on the expression of preproinsulin, glut-2, 


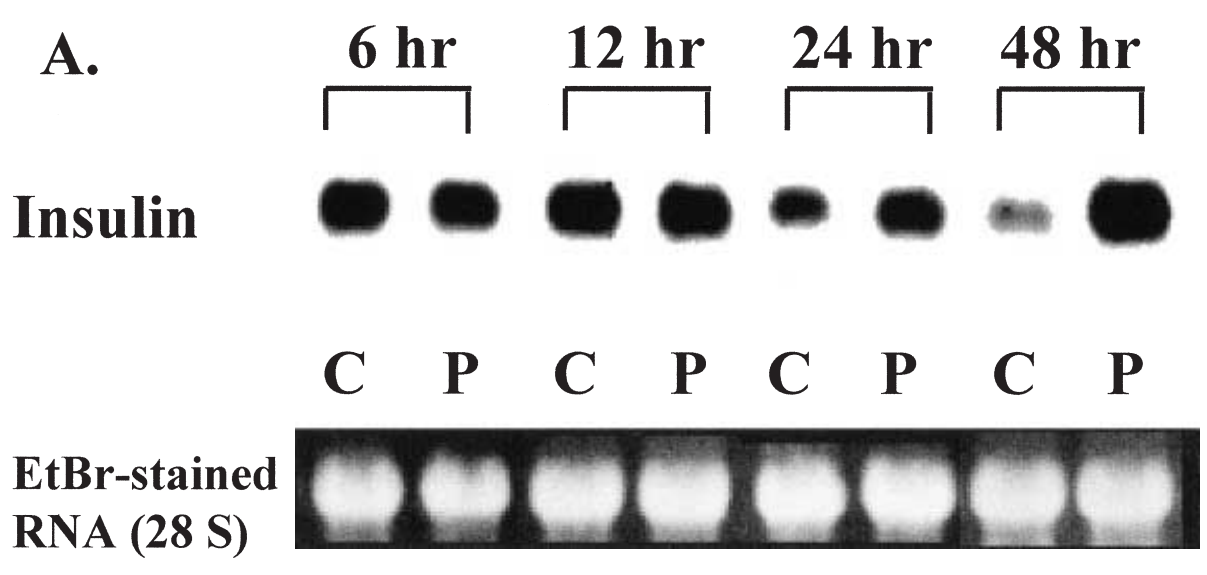

\section{B.}

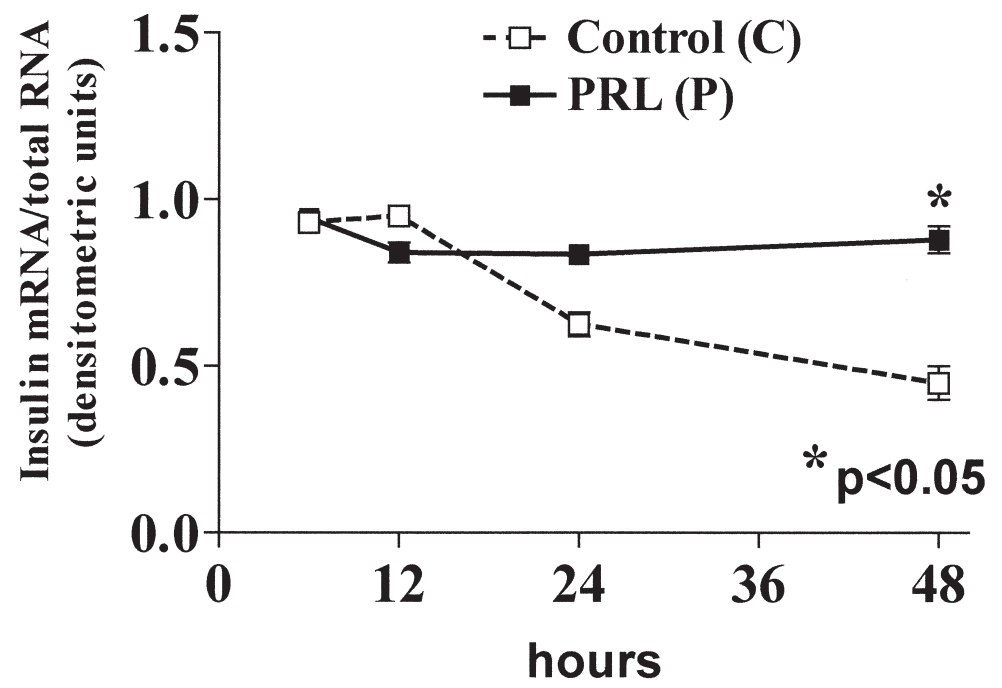

Figure 1 (A) Effect of PRL on preproinsulin mRNA levels in INS-1 cells incubated in glucosecontaining medium. INS-1 cells were grown in medium containing $10 \%$ FCS and $11 \cdot 1 \mathrm{mM}$ glucose. The medium was then replaced with serum-free 'basal medium' containing $5.5 \mathrm{mM}$ glucose, and the cells were incubated for $48 \mathrm{~h}$ in the presence or absence of PRL $(1 \mu \mathrm{g} / \mathrm{ml})$. The figure shows a representative Northern blot and EtBr-stained RNA of the corresponding samples. Similar results were obtained in four independent experiments. (B) Graphic representation of the changes in the levels of insulin mRNA over time, normalized for total RNA as assessed by EtBr staining of the gels.

and glucokinase mRNAs. INS-1 cells were grown to $80 \%$ confluence in medium containing $10 \%$ FCS and $11 \cdot 1 \mathrm{mM}$ glucose. In the presence of $10 \%$ FCS and $11 \cdot 1 \mathrm{mM}$ glucose, INS-1 cells appeared to be maximally stimulated and no effect of PRL on preproinsulin, glut-2, or glucokinase mRNAs could be discerned. Therefore, in subsequent experiments the incubations were performed in serum-free 'basal' (supplemented) medium containing $5.5 \mathrm{mM}$ glucose. The cells were incubated for $48 \mathrm{~h}$ in the presence or absence of PRL $(1 \mu \mathrm{g} / \mathrm{ml})$. The levels of the various mRNAs in PRL-treated cells were compared with mRNA levels in the control cells at various time-points. The levels of preproinsulin and glut-2 mRNAs declined progressively in control cells after replacement of serumcontaining medium with supplemented serum-free medium (Figs 1 and 2). However, the levels of preproinsulin and glut-2 mRNAs remained stable in serum-free medium containing PRL, and at $48 \mathrm{~h}$ of incubation the level of preproinsulin mRNA was $1 \cdot 7$-fold higher $(1 \cdot 71 \pm 0 \cdot 12, P<0 \cdot 05)$ in PRL-treated cells than in control 


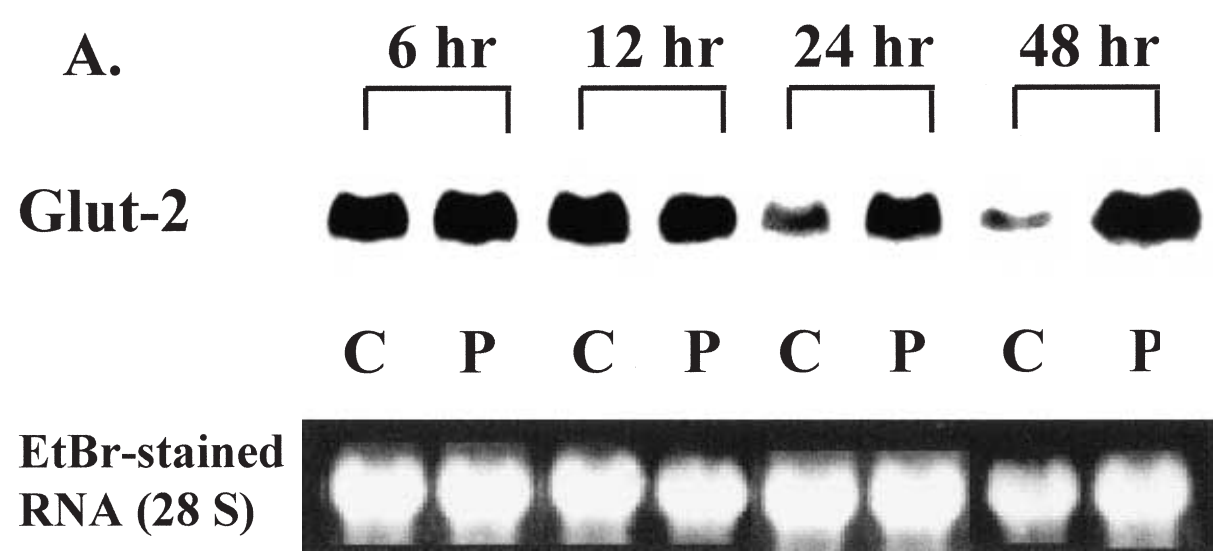

B.

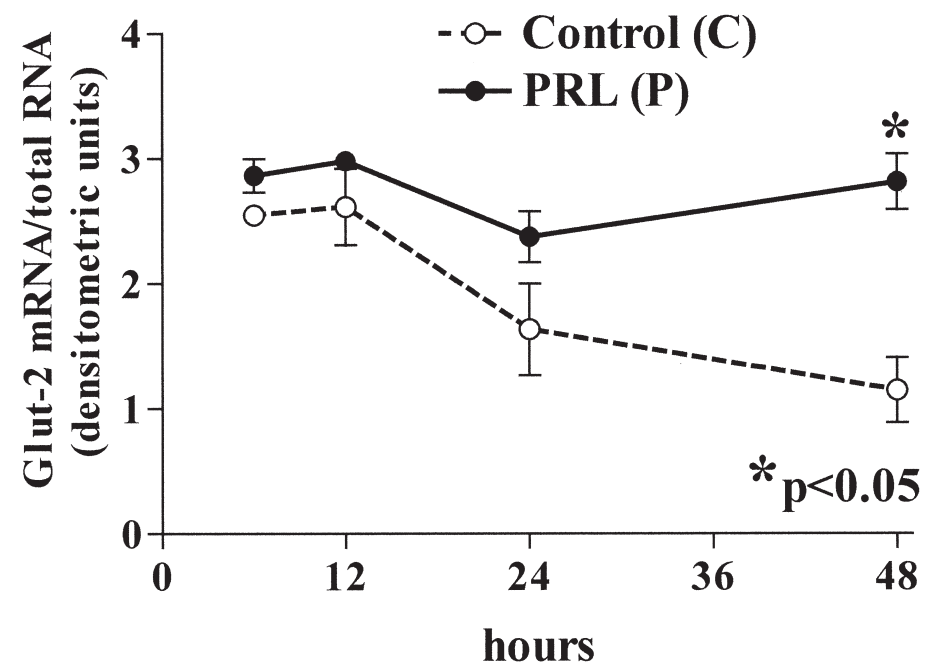

Figure 2 (A) Effect of PRL on glut-2 mRNA levels in INS-1 cells incubated in glucose-containing medium. INS-1 cells were grown in medium containing $10 \%$ FCS and $11 \cdot 1 \mathrm{mM}$ glucose. The medium was then replaced with serum-free 'basal medium' containing $5.5 \mathrm{mM}$ glucose, and the cells were incubated for $48 \mathrm{~h}$ in the presence or absence of PRL $(1 \mu \mathrm{g} / \mathrm{ml})$. The figure shows a representative Northern blot and EtBr-stained RNA of the corresponding samples. Similar results were obtained in four independent experiments. (B) Graphic representation of the changes in the levels of glut-2 mRNA over time, normalized for total RNA as assessed by EtBr staining of the gels.

cells (Fig. 1). Similarly, the level of glut-2 mRNA was $2 \cdot 0$-fold higher $(2 \cdot 04 \pm 0.56, P<0 \cdot 05)$ in PRL-treated cells than in control cells at $48 \mathrm{~h}$ of incubation (Fig. 2). Prolactin had no significant effect on the levels of glucokinase or IGF-II mRNAs (Fig. 3).

To determine whether the induction of glut-2 mRNA was accompanied by an increase in the number of cellular glucose transporters, we preincubated INS-1 cells in 'basal medium' for $48 \mathrm{~h}$ with or without PRL. The cells were washed with PBS and incubated with 2-deoxy-D$\left[{ }^{3} \mathrm{H}\right]$ glucose for periods of time ranging from 1 to $16 \mathrm{~min}$.
In both control and PRL-treated cells, the specific uptake of glucose increased between 1 and 16 min. However, the rate of glucose uptake in PRL-treated cells exceeded the rate of glucose uptake in control cells. At 1-4 min and at 16 min the uptake of 2-deoxy-D- $\left[{ }^{3} \mathrm{H}\right]$ glucose in PRLtreated cells was $2 \cdot 4-$ and $1 \cdot 4$-fold higher respectively than the uptake of 2-deoxy-D- $\left[{ }^{3} \mathrm{H}\right]$ glucose in diluent-treated cells $(P<0 \cdot 001$ by ANOVA; Fig. 4$)$.

To explore the role of glucose in PRL action, we examined the time-course of the effects of PRL on preproinsulin, glut-2, and glucokinase mRNAs in INS-1 


\title{
Glucokinase
}

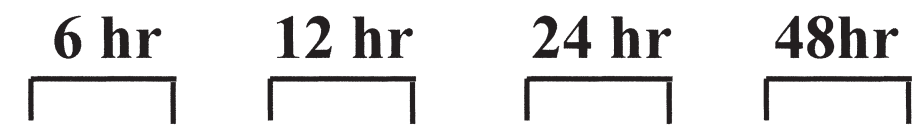

\author{
EtBr-stained \\ RNA (28 S)
}

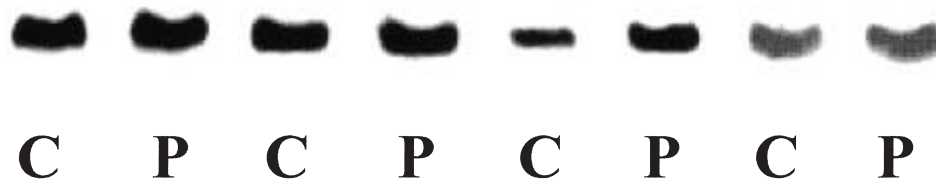

$\begin{array}{llllllll}\mathbf{C} & \mathbf{P} & \mathbf{C} & \mathbf{P} & \mathbf{C} & \mathbf{P} & \mathbf{C} & \mathbf{P}\end{array}$

B.

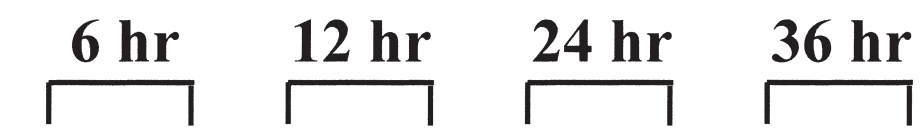

IGF-II

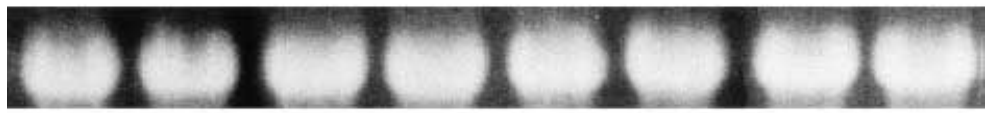

\section{EtBr-stained RNA (28 S)}
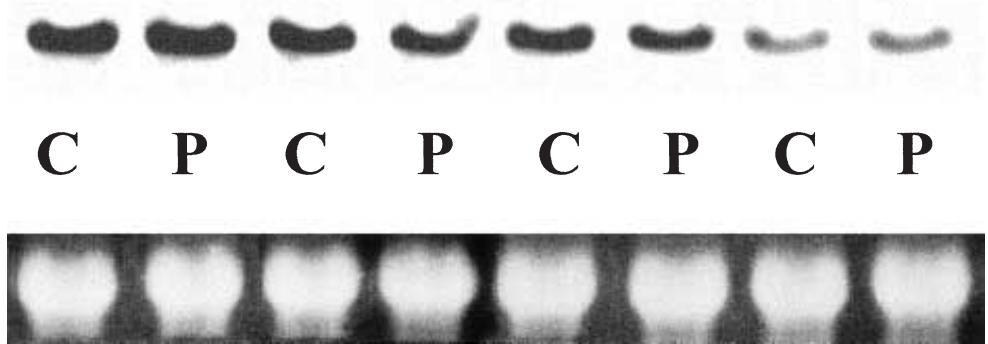

Figure 3 The effects of PRL on glucokinase (A) and IGF-II (B) mRNA levels. INS-1 cells were incubated for $48 \mathrm{~h}$ in serum-free 'basal medium' in the presence or absence of PRL (P; $1 \mu \mathrm{g} / \mathrm{ml})$. The figure shows representative Northern blots $(\mathrm{C}=$ control). Normalization for total RNA revealed that PRL had no statistically significant effects on either glucokinase or IGF-II mRNAs. Similar results were obtained in four independent experiments.

cells in the absence of exogenous glucose (Fig. 5). The levels of mRNA encoding preproinsulin declined progressively in control cells during a 24-h incubation in glucose-free medium. The levels of mRNA encoding glut-2 declined more precipitously in glucose-free medium, reaching a nadir after $8 \mathrm{~h}$ of incubation. In PRL-treated cells, on the other hand, the levels of preproinsulin mRNA increased progressively during the incubation in glucose-free medium and by $24 \mathrm{~h}$ were $3 \cdot 4$ fold higher $(3.38 \pm 0 \cdot 24, P<0 \cdot 0001)$ than those in control cells. PRL also stimulated an increase in glut- 2 mRNA in cells incubated in glucose-free medium. The maximal effects of PRL on glut-2 mRNA preceded the effects of the hormone on insulin mRNA and were noted within $8 \mathrm{~h}$ of incubation (2-fold increase, $2 \cdot 01 \pm 0 \cdot 09, P<0 \cdot 01)$. The effects of PRL on glucokinase expression are shown in Fig. 5C. The figure shows apparent inhibition of glucokinase expression by PRL; however, in an additional three experiments, PRL had no significant effect on the expression of glucokinase mRNA in the absence of glucose.

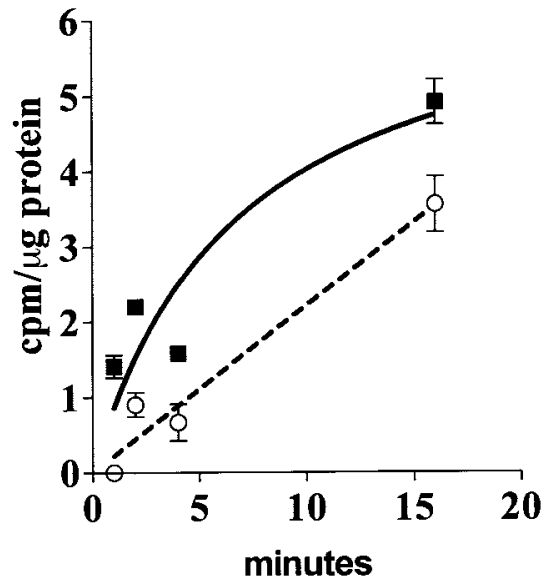

- Prolactin

o Control

Figure 4 The effect of PRL on 2-deoxy-D- $\left[{ }^{3} \mathrm{H}\right]$ glucose uptake in INS-1 cells. INS-1 cells were preincubated in 'basal medium' for $48 \mathrm{~h}$ with or without PRL. The cells were washed with PBS and incubated with 2-deoxy-D- $\left[{ }^{3} \mathrm{H}\right] \mathrm{glucose}$ for 1 to $16 \mathrm{~min}$. The data are presented as the means \pm S.E. of triplicate values. The effects of PRL were statistically significant at each time-point $(P<0 \cdot 01)$. 

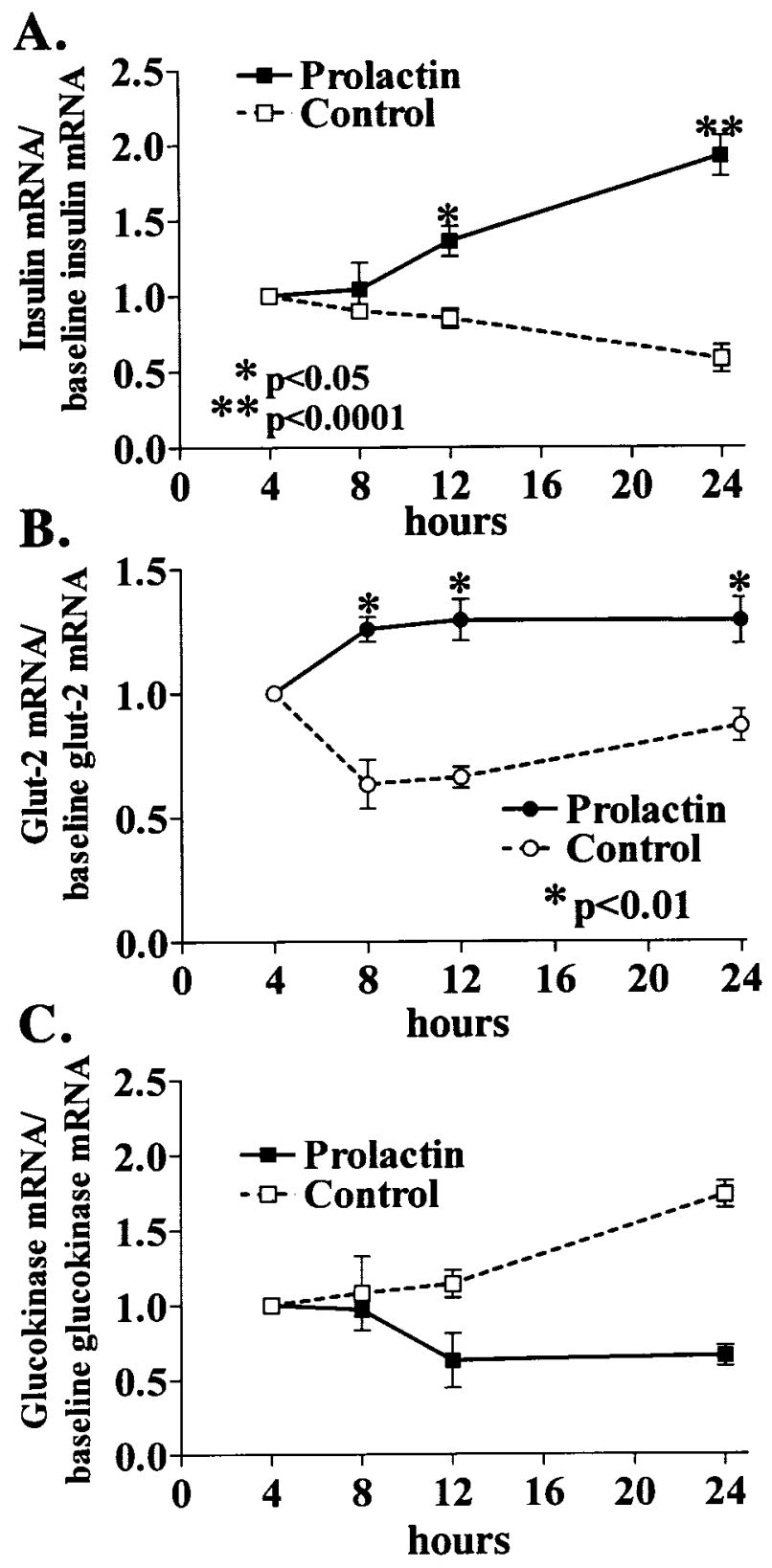

Figure 5 Time-course of the effects of PRL on preproinsulin (A), glut-2 (B), and glucokinase (C) mRNAs in cells incubated in glucose-free medium. The cells were incubated in serum-free, glucose-free DMEM with $1 \mathrm{mM}$ sodium pyruvate for $2 \mathrm{~h}$ prior to, and for $24 \mathrm{~h}$ after, the addition of PRL or diluent. The figures are graphic representations of the changes in the levels of preproinsulin, glut-2, and glucokinase mRNAs over time, normalized for total RNA as assessed by EtBr staining of the gels. The levels of preproinsulin, glut-2, and glucokinase mRNAs were compared with the levels of corresponding mRNAs $4 \mathrm{~h}$ after the addition of PRL. In other experiments there were no differences in the levels of the various mRNAs during the initial $4 \mathrm{~h}$ of incubation in control or PRL-containing media.
These findings suggested that PRL has glucoseindependent as well as glucose-dependent effects on the expression of insulin mRNA. Since the levels of preproinsulin mRNA in control cells declined significantly from baseline during incubations in both glucose-replete and glucose-depleted media, the effect of PRL could be mediated by stabilization of preproinsulin mRNA and/or by the induction of preproinsulin gene transcription.

To determine whether the PRL effect on insulin mRNA levels results from induction of insulin gene transcription, we examined the effects of PRL on the activity of the insulin promoter (Fig. 6). To that end, we transfected INS-1 cells with a plasmid containing the rat insulin 1 promoter linked to a luciferase reporter gene. After an overnight incubation in RPMI containing 10\% FCS, the cells were incubated for an additional $24 \mathrm{~h}$ with PRL or diluent in serum-free basal medium containing varying concentrations of glucose $(0-11 \mathrm{mM})$.

In the absence of glucose $(0 \mathrm{mM}$ glucose $)$, PRL stimulated a $3 \cdot 4$-fold increase in cellular luciferase activity $(3.41 \pm 0.34, P<0.01)$. This finding indicates that PRL stimulates insulin gene transcription directly, in a glucoseindependent manner. Glucose alone at $5.5 \mathrm{mM}$ stimulated a 2-2-fold increase in cellular luciferase activity $(2 \cdot 23 \pm 0.07, P<0 \cdot 001)$. However, the combination of PRL plus $5 \cdot 5 \mathrm{mM}$ glucose stimulated a $7 \cdot 9$-fold increase in luciferase activity $(7 \cdot 86 \pm 0 \cdot 36, P<0 \cdot 0001)$. Thus, the combined effect of glucose plus PRL on cellular luciferase activity $(7 \cdot 9$-fold greater than that of cells incubated in glucose-free, PRL-free medium) was $41 \cdot 1 \%$ greater than the sum of the effects of glucose alone and PRL alone $(2 \cdot 2-$ and 3.4-fold increase respectively). Similar results were obtained in experiments in which cells were incubated in media containing $11 \mathrm{mM}$ glucose. At a concentration of $11 \mathrm{mM}$, glucose alone stimulated a $1 \cdot 6$-fold increase in luciferase activity $(1 \cdot 64 \pm 0 \cdot 11, P<0 \cdot 05)$. The effect of $11 \mathrm{mM}$ glucose plus PRL on cellular luciferase activity (7.5-fold greater than that of cells incubated in glucosefree, PRL-free medium, $7 \cdot 52 \pm 0 \cdot 07, \quad P<0 \cdot 0001)$ was $48.9 \%$ greater than the sum of the effects of $11 \mathrm{mM}$ glucose alone (1.6-fold increase) and PRL alone (3.4-fold increase). These observations indicate that PRL and glucose act synergistically to stimulate insulin gene transcription.

\section{Discussion}

The lactogenic hormones placental lactogen and PRL stimulate beta-cell proliferation (Brelje \& Sorenson 1991, Brelje et al. 1993, 1994), insulin biosynthesis (Nielsen 1982, Markoff et al. 1990, Galsgaard et al. 1996), glucosestimulated insulin secretion (Sorenson et al. 1987a, Brelje et al. 1993), and gap junctional coupling among beta cells (Sorenson et al. 1987a,b). The results of our studies suggest that the effects of PRL on insulin gene expression are 
Glucose (mM)

Prolactin

\section{Fold increase} in luciferase activity

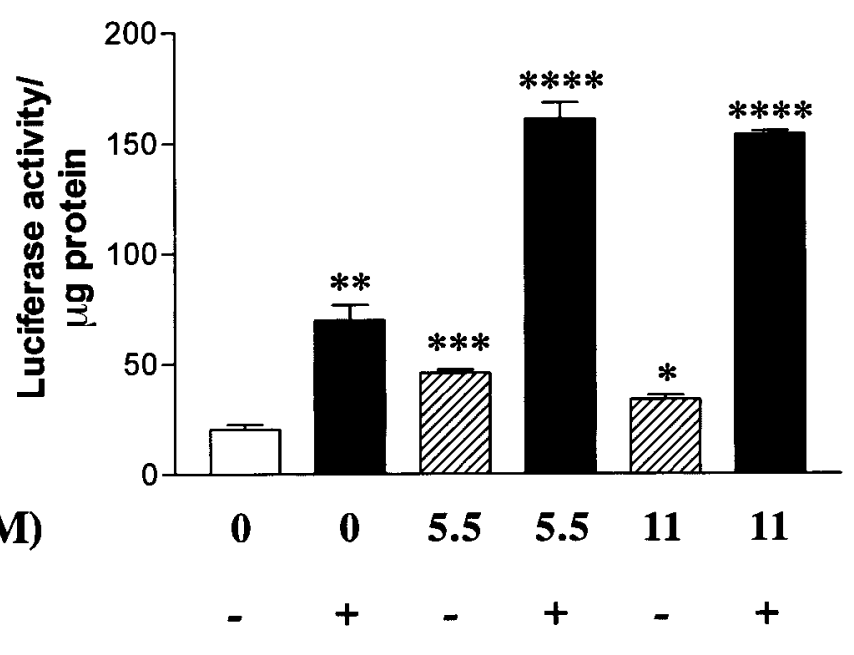

$\begin{array}{lllll}3.4 & 2.2 & 7.9 & 1.6 & 7.5\end{array}$

Figure 6 Effects of glucose and PRL on insulin promoter activity. All INS-1 cells were transfected at the same time under identical conditions with a plasmid containing the rat insulin 1 promoter linked to a luciferase reporter gene. All cells were cotransfected with an RSV-beta-GAL construct. After an overnight incubation in serum-containing medium, the cells were incubated for $24 \mathrm{~h}$ in serum-free medium containing varying concentrations of glucose and PRL. Luciferase activity was normalized for cellular protein levels. The beta-galactoside levels in the control and PRL-treated cells were comparable and statistically indistinguishable at the various glucose concentrations. The data represent the means \pm S.E. of triplicate samples. Similar results were obtained in five additional experiments. The luciferase activities in the various treatment groups were compared with the luciferase activity in cells incubated in glucose-free, PRL-free medium. ${ }^{*} P<0 \cdot 05$, ${ }^{* *} P<0 \cdot 01,{ }^{* *} P<0 \cdot 001,{ }^{* * * *} P<0 \cdot 0001$.

mediated through both glucose-dependent and glucoseindependent mechanisms. A role for glucose in PRL action is suggested by four lines of evidence: first, PRL increases the levels of glut-2 mRNA and stimulates cellular glucose uptake in INS-1 cells in culture; secondly, in the presence of glucose, the time-course of induction of glut-2 mRNA by PRL parallels that of insulin mRNA; thirdly, the effects of PRL on insulin gene transcription are blunted when cells are incubated in the absence of glucose; and finally, the effects of PRL are similar to those of glucose itself, which induces expression of glut-2 and insulin in pancreatic islets (Docherty \& Clark 1994, Philippe et al. 1994, the current study). These observations suggest that the effects of PRL on insulin gene transcription may be mediated in part by induction of glucose transport and/or glucose metabolism.

The rate-limiting step in glucose metabolism in pancreatic beta cells is the activity of the enzyme glucokinase (Grupe et al. 1995). Previous studies have demonstrated the induction by PRL of immunoreactive glucokinase in cytosolic extracts of pancreatic islets (Weinhaus et al. 1996). However, we detected no significant effect of PRL on the levels of glucokinase mRNA in INS-1 cells. It is possible that the effects of PRL on glucokinase immunoreactivity may be exerted at a post-transcriptional level.

While glucose may mediate, in part, the effects of PRL on glut-2 and insulin production, it is clear that PRL also exerts glucose-independent effects on glut- 2 and insulin gene expression. In the absence of glucose, PRL increased the levels of glut-2 mRNA and insulin mRNA. In addition, PRL activated the insulin promoter under glucose-free conditions, albeit to a lesser extent than in cells incubated in $5.5 \mathrm{mM}$ glucose. These observations indicate that the mechanisms by which PRL exerts its effects in islet cells must differ in part from the mechanisms by which glucose exerts its insulinotropic effects.

Support for this hypothesis comes from studies of insulin gene expression in which we compared directly the effects of glucose and PRL alone or in combination. Glucose $(5 \cdot 5 \mathrm{mM})$ alone stimulated a $2 \cdot 2$-fold increase in insulin promoter activity, while PRL alone stimulated a 3·4-fold increase in promoter activity. However, glucose and PRL in combination acted synergistically to stimulate a 7.9-fold 
increase in promoter activity relative to diluent-treated cells incubated in the absence of glucose or PRL. Likewise, the effect of $11 \mathrm{mM}$ glucose plus PRL on insulin promoter activity $(7 \cdot 5$-fold increase relative to glucosefree, PRL-free controls) was approximately $50 \%$ greater than the sum of the effects of $11 \mathrm{mM}$ glucose alone (1.6-fold increase) and PRL alone (3.4-fold increase). The synergism of glucose and PRL in combination indicates that the nutrient and the hormone induce insulin gene transcription, at least in part, through distinct mechanisms.

The effect of PRL on insulin gene transcription may be mediated by activation of the JAK-STAT pathway (Sorenson et al. 1987b, Rui et al. 1994, Galsgaard et al. 1996, Pezet et al. 1997, Bole-Feysot et al. 1998). PRL stimulates nuclear translocation of Stat 5 in INS-1 cells (Stout et al. 1997), and human growth hormone (hGH), which binds to prolactin receptors as well as $\mathrm{GH}$ receptors, induces the binding of an immunoreactive Stat 5 protein to gamma-interferon activated-like sequences in the insulin promoter of RIN-5AH rat insulinoma cells (Galsgaard et al. 1996). PRL also activates a number of other cellular kinases including FYN and the $85 \mathrm{kDa}$ subunit of the phosphatidyl-inositol (PI)-3' kinase. The roles of the Jak, Fyn and PI-3 kinases in the interactions between PRL and glucose are unclear. Both glucose and PRL stimulate $\mathrm{Ca}^{2+}$ uptake by insulin-secreting cells (Sekine et al. 1996, Crepaldi et al. 1997), which may provide one common mechanism by which PRL and glucose stimulate insulin gene expression.

Clinical observations support a role for lactogenic hormones in the regulation of insulin gene expression. In pregnancy, high concentrations of PRL and placental lactogen in maternal serum are accompanied by increases in beta-cell mass, insulin production and glucosedependent insulin secretion (Hellman 1960, Green \& Taylor 1972, Bone \& Taylor 1976, Ogren \& Talamantes 1988, Parsons et al. 1992, 1995). Moreover, female patients with hyperprolactinemia have exaggerated insulin secretory responses to arginine (Maccario et al. 1996). Although the insulin response to glucose alone is not different from that observed in normal women, the combination of glucose and arginine in hyperprolactinemic women has an additive effect on insulin secretion.

The effects of lactogens on insulin production may be amplified by positive feedback effects of insulin on the production of lactogens. Insulin stimulates the secretion of placental lactogen in human placental explants and rat trophoblast cells in culture (Bhaumick et al. 1987, Kishi et al. 1993). In addition, insulin acts at the level of the pituitary to induce PRL gene transcription (Jacob \& Stanley 1995). Thus, lactogenic and pancreatic hormones may interact at multiple levels to regulate carbohydrate metabolism in pregnancy and in various pathologic states.

\section{Acknowledgements}

This work was supported by grants from the NIH (HD-24192), Juvenile Diabetes Foundation (196029), and Eli Lilly and Company.

\section{References}

Asfari M, Janjic D, Meda P, Li G, Halban PA \& Wollheim CB 1992 Establishment of 2-mercaptoethanol-dependent differentiated insulin-secreting cell lines. Endocrinology 130 167-178.

Asfari M, De W, Postel-Vinay MC \& Czernichow P 1995 Expression and regulation of growth hormone $(\mathrm{GH})$ and prolactin (PRL) receptors in a rat insulin producing cell line (INS-1). Molecular and Cellular Endocrinology 107 209-214.

Bhaumick B, Dawson EP \& Bala RM 1987 The effects of insulin-like growth factor-I and insulin on placental lactogen production by human term placental explants. Biochemical and Biophysical Research Communications 144 674-682.

Bole-Feysot C, Goffin V, Edery M, Binart N \& Kelly PA 1998 Prolactin (PRL) and its receptor: actions, signal transduction pathways and phenotypes observed in PRL receptor knockout mice. Endocrine Reviews 19 225-268.

Bone AJ \& Taylor KW 1976 Metabolic adaptation to pregnancy shown by increased biosynthesis of insulin in islets of Langerhans isolated from pregnant rat. Nature 262 501-502.

Brelje TC \& Sorenson RL 1991 Role of prolactin versus growth hormone on islet B-cell proliferation in vitro: implications for pregnancy. Endocrinology 128 45-57.

Brelje TC, Scharp DW, Lacy PE, Ogren L, Talamantes F, Robertson M, Friesen HG \& Sorenson RL 1993 Effect of homologous placental lactogens, prolactins, and growth hormones on islet B-cell division and insulin secretion in rat, mouse, and human islets: implication for placental lactogen regulation of islet function during pregnancy. Endocrinology 132 879-887.

Brelje TC, Parsons JA \& Sorenson RL 1994 Regulation of islet betacell proliferation by prolactin in rat islets. Diabetes 43 263-273.

Crepaldi SC, Carneiro EM \& Boschero AC 1997 Long-term effect of prolactin treatment on glucose-induced insulin secretion in cultured neonatal rat islets. Hormone and Metabolic Research 29 220-224.

Docherty K \& Clark AR 1994 Nutrient regulation of insulin gene expression. FASEB Journal 8 20-27.

Freemark M, Nagano M, Edery M \& Kelly PA 1995 Prolactin receptor gene expression in the fetal rat. Journal of Endocrinology 144 285-292.

Frödin M, Sekine N, Roche E, Filloux C, Prentki M, Wollheim CB \& Van Obberghen E 1995 Glucose, other secretagogues, and nerve growth factor stimulate mitogen-activated protein kinase in the insulin-secreting beta-cell line, INS-1. Journal of Biological Chemistry $2707882-7889$.

Galsgaard ED, Gouilleux F, Groner B, Serup P, Nielsen JH \& Billestrup N 1996 Identification of a growth hormone-responsive STAT5-binding element in the rat insulin 1 gene. Molecular Endocrinology 10 652-660.

Green IC \& Taylor KW 1972 Effects of pregnancy in the rat on the size and insulin secretory response of the islets of Langerhans. Journal of Endocrinology 54 317-325.

Grupe A, Hultgren B, Ryan A, Ma YH, Bauer M \& Stewart TA 1995 Transgenic knockouts reveal a critical requirement for pancreatic beta cell glucokinase in maintaining glucose homeostasis. Cell 83 69-78.

Hellerstrom C, Sjoholm A \& Swenne I 1991 Effects of growth hormone and related growth factors on DNA replication and insulin production in pancreatic islet beta cells. Acta Paediatrica Scandinavica (Suppl) 377 55-62. 
Hellman B 1960 The islets of Langerhans in the rat during pregnancy and lactation, with special reference to the changes in the B/A cell ratio. Acta Obstetricia et Gynecologica Scandinavica 39 331-342.

Jacob KK \& Stanley FM 1995 Insulin and cyclic adenosine monophosphate increase prolactin gene expression through different response pathways. Molecular and Cellular Endocrinology 109 175-181.

Kishi K, Itoh M, Kanamori S, Hirashiba M \& Kawai M 1993 Stimulation of rat placental lactogen-II (rPL-II) secretion by cultured trophoblasts by insulin: development of a rat placental cell culture system and effects of peptide hormones on rPL-II secretion in vitro. Journal of Reproduction and Fertility 99 519-527.

Maccario M, Grottoli S, Razzore P, Procopio M, Oleandri SE, Ciccarelli E, Camanni F \& Ghigo E 1996 Effects of glucose load and/or arginine on insulin and growth hormone secretion in hyperprolactinemia and obesity. European Journal of Endocrinology 135 205-210.

Markoff E, Beattie GM, Hayek A \& Lewis UJ 1990 Effects of prolactin and glycosylated prolactin on (pro)insulin synthesis and insulin release from cultured rat pancreatic islets. Pancreas $\mathbf{5}$ 99-103.

Moldrup A, Petersen ED \& Nielsen JH 1993 Effects of sex and pregnancy hormones on growth hormone and prolactin receptor gene expression in insulin-producing cells. Endocrinology $\mathbf{1 3 3}$ $1165-1172$.

Nielsen JH 1982 Effects of growth hormone, prolactin, and placental lactogen on insulin content and release, and deoxyribonucleic acid synthesis in cultured pancreatic islets. Endocrinology $\mathbf{1 1 0}$ 600-606.

Ogren L \& Talamantes F 1988 Prolactins of pregnancy and their cellular source. International Review of Cytology 112 1-65.

Parsons JA, Brelje TC \& Sorenson RL 1992 Adaptation of islets of Langerhans to pregnancy: increased islet cell proliferation and insulin secretion correlates with the onset of placental lactogen secretion. Endocrinology 130 1459-1466.

Parsons JA, Bartke A \& Sorenson RL 1995 Number and size of islets of Langerhans in pregnant, human growth hormone-expressing transgenic, and pituitary dwarf mice: effect of lactogenic hormones. Endocrinology 136 2013-2021.

Pezet A, Buteau H, Kelly PA \& Edery M 1997 The last proline of Box 1 is essential for association with JAK2 and functional activation of the prolactin receptor. Molecular and Cellular Endocrinology 129 199-208.

Philippe J, Pacheco I \& Meda P 1994 Insulin gene transcription is decreased rapidly by lowering glucose concentrations in rat islet cells. Diabetes 43 523-528.
Rui H, Kirken RA \& Farrar WL 1994 Activation of receptorassociated tyrosine kinase JAK2 by prolactin. Journal of Biological Chemistry 269 5364-5368.

Sambrook J, Fritsch EF \& Maniatis T 1989 Molecular Cloning: A Laboratory Manual, pp 16-66. New York: Cold Spring Harbor Laboratory Press.

Sekine N, Ullrich S, Regazzi R, Pralong WF \& Wollheim CB 1996 Postreceptor signaling of growth hormone and prolactin and their effects in the differentiated insulin-secreting cell line, INS-1. Endocrinology 137 1841-1850.

Sorenson RL \& Stout LE 1995 Prolactin receptors and JAK2 in islets of Langerhans: an immunohistochemical analysis. Endocrinology 136 4092-4098.

Sorenson RL, Johnson MG, Parsons JA \& Sheridan JD 1987a Decreased glucose stimulation threshold, enhanced insulin secretion, and increased beta cell coupling in islets of prolactin-treated rats. Pancreas 2 283-288.

Sorenson RL, Brelje TC, Hegre OD, Marshall S, Anaya P \& Sheridan JD $1987 b$ Prolactin (in vitro) decreases the glucose stimulation threshold, enhances insulin secretion, and increases dye coupling among islet B cells. Endocrinology 121 1447-1453.

Sorenson RL, Brelje TC \& Roth C 1993 Effects of steroid and lactogenic hormones on islets of Langerhans: a new hypothesis for the role of pregnancy steroids in the adaptation of islets to pregnancy. Endocrinology 133 2227-2234.

Stout LE, Svensson AM \& Sorenson RL 1997 Prolactin regulation of islet-derived INS-1 cells: characteristics and immunocytochemical analysis of STAT5 translocation. Endocrinology 138 1592-1603.

Tai PK, Liao JF, Chen EH, Dietz J, Schwartz J \& Carter-Su C 1990 Differential regulation of two glucose transporters by chronic growth hormone treatment of cultured 3T3-F442A adipose cells. Journal of Biological Chemistry 265 21828-21834.

Waeber G, Thompson N, Haefliger JA \& Nicod P 1994 Characterization of the murine high $\mathrm{Km}$ glucose transporter GLUT2 gene and its transcriptional regulation by glucose in a differentiated insulin-secreting cell line. Journal of Biological Chemistry 269 26912-26919.

Weinhaus AJ, Stout LE \& Sorenson RL 1996 Glucokinase, hexokinase, glucose transporter 2, and glucose metabolism in islets during pregnancy and prolactin-treated islets in vitro: mechanisms for long term up-regulation of islets. Endocrinology 137 1640-1649.

Received 17 June 1999

Accepted 28 September 1999 